\title{
KEEFEKTIFAN MODEL PEMBELAJARAN BERBASIS PROYEK DALAM MENINGKATKAN KOMPETENSI MENYUSUN GENRE TEKS PROSEDURAL PADA SISWA KELAS VIII SMP DIPONEGORO SUMBAWA BESAR
}

\author{
Oleh \\ Sri Sugiarto \\ Dosen Prodi Pendidikan Bahasa, FKIP Universitas Samawa \\ Email: Sri.sugiarto90@gmail.co.id
}

\begin{abstract}
Abstrak
Menghadapi perubahan kurikulum tingkat satuan pendidikan (KTSP) dengan kurikulum 2013 (K13) perlu dilakukan pematangan komponen-komponen pembelajaran salah satunya dengan cara uji coba model-model pembelajaran yang tepat digunakan. Sejalan dengan hal tersebut, penelitian ini memiliki tujuan untuk melihat kefektifan model pembelajaran berbasis proyek tehadap kemampuan menulis genre teks posedural. Sebagai upaya yang dilakukan untuk mencapai tujuan tersebut, maka dipilih jenis penelitian menggunakan jenis penelitian kuantitatif dengan pendekatan quasi eksperimen serta desain penelitiannya menggunakan One Group Pretest-Posttest Design. Populasi penelitian sejumlah 92 siswa yang terbagi kedalam empat kelompok belajar, yaitu siswa kelas VIII1-VIII4. Karena menggunakan desian one group pretest-posttest maka perlu ditentukan sampel penelitian dengan teknik purposive sampling. Sehingga dipilih siswa kelas VIII2 untuk dijadikan sampel kelas eksprimen. Teknik pengumpulan data dilakukan dengan teknik tes dan nontes. Teknik analisis data dilakukan melalui dua tahapan, yaitu analisis awal dan analisis akhir. Data awal/pretes diuji normalitas untuk mengetahui apakah data berdistribusi normal atau tidak. Data akhir/postes diuji normalitas dan selanjutnya dilakukan pengujian hipotesis dengan uji gain dan uji perbedaan dua rata-rata (uji t). Hasil analisis menunjukkan bahwa aspek sikap secara klasikal meningkat dengan kategori sedang sebesar 0,53 , aspek pengetahuan secara klasikal meningkat dengan kategori sedang sebesar 0,68 dan aspek keterampilan secara klasikal meningkat dengan kategori tinggi sebesar 0,71.
\end{abstract}

Kata Kunci: model pembelajaran berbasis proyek, kefektifan, genre teks procedural.

\section{PENDAHULUAN}

Paradigma kehidupan dan ilmu pengetahun dalam ke 21 kini memang dirasakan sudah mulai ada pergeseran baik ciri maupun model pembelajaran. Ciri pembelajaran abad ke 21 dapat kita cermati beberapa titik penekenan arahan pembelajaran, seperti pembelajaran diarahkan untuk mendorong siswa mencari tahu dari berbagai sumber obeservasi. Hal ini didukung sumber informasi pada abad ini tersedia dimana dan kapan saja dibutuhkan. Ciri lainya, pembelajaran diarahkan untuk mampu merumuskan masalah dan dapat menyelsaikan masalah. Selain itu, pembelajaran pada abad ini juga diarahkan untuk melatih berpikir analitis. Serta pembelajaran juga harus ditekankan pada pentingnya kerjasama dan kolaborasi dalam menyelsaikan masalah. Dari beberapa ciri-ciri tersebut, pemerintah telah mengantisipasi dengan menyusun kurikulum 2013. Litbang, (2013) kurkulum ini 
diharapkan dapat menghasilkan insan Indonesia yang produktif, kreatif, inovatif, dan efektif melalui penguatan sikap, keterampilan, dan pengetahuan yang terintegrasi.

Dengam mencermati hasil penelitian oraganisasi dunia seperti IEA dengan progam PIRLS (2011) diakui bahwa kemampuan berbahasa siswa di Indonesia masih sangat rendah. Siswa di Indonesia dalam kemapuan pada ranah kognitp level awal 66\%, level sedang 28\%, level tinggi 4\%, dan level yang paling sempurna 0,1 \%, (http://www.iea.nl/pirls_2011.html). Artinya, siswa di Indonesia pada kemampuan berbahasa pada lebih rendah memiliki kemampuan lebih tinggi sedangkan kemapuan berbahasa pada lebih sempurna (kompleks) sangat rendah.

Upaya yang dilakukan pemerintah dalam hal ini Kementerian Pendidikan melakuan perubahan kurikulum. Di Indonesia, perubahan kurikulum sudah dilakukan 6 kali mulai penerapan kurikulum 1968, kurikulum 1975, kurikulum 1984, kurikulum 1994, kurikulum berbasis kompetensi (KBK), kurikulum tingkat satuan pendidikan (KTSP) dan yang sedang dirapkan kurikulum 2013 (K13).

Pembelajaran bahasa Indonesia dalam kurikulum 2013 seperti apa yang dikemukan, Mahsun (2014: 94) pembelajaran bahasa Indonesia berorientasi pada pembelajaran berbasis teks. Pembelajaran berbasis teks memiliki tujuan agar pembelajar dapat memahami ilmu pengetahuan melalui teks yang disajikan sesuai dengan tujuan sosial tertentu. Karena teks merupakan satuan bahasa yang terkecil dengan struktur berpikir (makna) yang lengkap, maka dalam pembelajaran diperlukan tahapan-tahapan dalam pembelajaran berbasis teks.

Berdasarkan kondisi tersebut, diakui bahawa pembelajaran di Indonesia terutama pelajaran bahasa sangat bermasalah. Oleh karena itu, perlu adanya suatu inovasi dan kreatifitas dalam menangani kondisi tersebut. Dalam penelitian ini, inovasi dan kreatifitas difokuskan pada uji coba model pembelajaran dengan melihat kefektifan dala pembelajaran menulis genre teks. Berlandasakan latar belakang tersebut, dirumuskan rumusan penelitian ini dalam kalimat pertanyaan, yaitu bagaimanakah efektifan pembelajaran berbasis proyek dalam meningkatkan kompetensi sikap, pengetahuan, dan keterampilan menulis teks genre prosedural siswa SMP Diponegeoro Sumbawa Besar?

Pembelajaran Berbasis Proyek merupakan model pembelajaran yang menggunakan masalah sebagai langkah awal dalam mengumpulkan dan mengintegrasikan pengetahuan berdasarkan pengalaman mahasiswa dalam beraktivitas secara nyata. PBL dirancang untuk digunakan pada permasalahan komplek yang diperlukan siswa dalam melakukan investigasi dan memahaminya. Model pembelajaran berbasis proyek dapat dipandang sebagai salah satu model penciptaan lingkungan belajar yang dapat mendorong siswa mengkonstruk pengetahuan dan keterampilan secara personal (Mahsun 2014: 205). Adanya peluang untuk menyampaikan ide, mendengarkan ide-ide orang lain, dan mereflesikan ide sendiri pada ide-ide orang lain, adalah suatu bentuk pengalaman pemberdayaan pengetahuan (meaning making process). Selain itu siswa juga untuk mengalami tahap pembelajaran yang disebut sebagai "Interactive Research Cycle" yang terdiri dari tahap pertanyaan, perencanaan, pengumpulan data, mensintesis pengetahuan, dan evaluasi. 
Model pembelajaran berbasis proyek adalah pembelajaran yang menitikberatkan pada aktivitas siswa untuk dapat memahami suatu konsep dan prinsip dengan melakukan investigasi yang mendalam tentang suatu masalah dan mencari suatu solusi yang relevan serta diimplementasikan dalam pengerjaan proyek, sehingga siswa mengalami proses pembelajarn yang bermakna dengan membangun pengetahuannya sendiri (Gintings, 2008: 95). Pembelajaran berbasis proyek sebuah antara kemampuan berteori serta keterampilan praktik. Salah satu model yang memiliki konsepsi berbasis pada praktik yaitu model pembelajaran berbasis proyek. Suratno et al. (dalam Sudarya, 2008: 235) menyatakan bahwa pebelajaran berbasis proyek merupakan suatu pengajaran yang dikembangkan berdasarkan prinsip konstruktivisme, problem solving, inquiry riset, integrated studies dan refleksi model pembelajaran yang inovatif, dan lebih menekankan pada belajar kontekstual melalui kegiatan-kegiatan yang kompleks (Wena 2010:145). Dalam pembelajaran berbasis proyek ini berfokus pada pembelajaran yang terletak pada prinsip dan konsep inti dari suatu disiplin ilmu, melibatkan siswa dalam investigasi dalam pemecahan masalah dan kegiatan tugas-tugas yang bermakna lainnya, dan memberi kesempatan siswa bekerja secara otonom dalam mengkonstruksi pengetahuan mereka sendiri, dan puncaknya untuk menghasilkan produk nyata. Pembelajaran berbasis proyek memiliki potensi yang besar untuk memberi pengalaman belajar yang lebih menarik dan bermakna bagi siswa.

Dalam pembelajaran menyusun teks, Mahsun (2014: 125) menguraikan langkah penggunaan model ini dengan 4 langkah, yakni (1) Tahapan membangun konteks, (2) tahap pemodelan (3) tahap kerja sama, (4) tahap mandiri. Dalam penelitian ini, penerapan 4 langkah model pembelajaran tersebut diombinasikan dengan langka model pembelajaran berbasisi proyek (Kemendikbud 2014), yaitu (1) penentuan proyek dan pertanyaan mendasar, (2) menyusun langkah perencanaan dan penyelesaian proyek, (3) menyusun jadwal pelaksanaan proyek, (4) penyelesaian proyek dan monitoring, (5) penyusunan laporan dan presentasi, dan (6) evaluasi pengalaman, proses, dan hasil.

\section{METODE PENELITIAN}

Jenis penelitian menggunakan pendekatan kuantitatif dengan pendekatan pre-exprimental design yang mengunakan one gruoup pretest-postest design. Penggunan desain ini dilakukan dengan memberikan pretest terhadap sampel penelitian yang terdiri atas satu kelas eksprimen. Selanjutnya, kelas eksprimen diberikan perlakuan pembelajaran model berbasis proyek. Setelah itu diberikan pos test. Nilai pos test ini akan dibdaningkan dengan nilai yang nilai KKM mata pelajaran bahasa Indonesia di SMP Ponegero Sumbawa Besar $\geq 80$.

Table 1. Desain Penelitian One Group Pretest-Posttest Design, Sugiono (2013:110)

\begin{tabular}{lccc}
\hline Kelompok & Pretest & Perlakuan & postest \\
\hline Kelas eksprimen & $\mathrm{O} 1$ & $\mathrm{X}$ & $\mathrm{O} 2$
\end{tabular}

Populasi penelitian sejumlah 92 siswa yang terbagi kedalam empat kelompok belajar, yaitu siswa kelas VIII1-VIII4. Karena menggunakan desian one group pretest-posttest maka perlu ditentukan sampel penelitian dengan teknik purposive sampling. Sehingga dipilih siswa kelas VIII2 untuk dijadikan sampel kelas eksprimen dengan pertimbangan siswa kelas ini memiliki tingkat kompetensi yang hampir sama. 
Variabel bebas penelitian, yakni model pembelajaran berbasisi teks. Sedangkan variabel terikatnya, yaitu kompetensi siswa terhadap pembelajaran menulis genre teks procedural. Kompetensi tersebut meliputi kompetensi sikap, pengetahun, serta keterampilan.

Teknik pengumpulan data dilakukan dengan teknik tes dan nontes. Teknik tes digunakan untuk mendapat data pengukuran kemampuan peserta didik dalam memahami dan menyusun teks prosedural secara tertulis. Teknik nontes digunakan untuk mengetahui sikap kemandirian belajar peserta didik selama perlakuan. Uji validitas instrumen menggunakan pengujian dari pakar yang dalam hal ini yaitu guru, dan pengawas pendidikan. Masing-masing sub aspek diberi penilaian dengan skor yang bergerak dari 0,1,2,3, (skor 0,1 tidak relevan, dan skor 2,3 relevan). Sokr-skor dari masingmasing penilai diolah dan dianalisis dengan menggunakan rumus Gregory yaitu $\frac{D}{A+B+C+D}$, dimana A : kedua penilai menilai tidak relevan, $\mathrm{B}, \mathrm{C}$ : kedua penilai memberi penilaian yang berbeda, dan D : kedua penilai menilai relevan. Hasil analisis ini dinterpretasikan dengan menggunakan kriteria: 0,800 - 1,000 sangat tinggi, $0.600-0,800$ tinggi, 0,400 - 0,600 cukup, 0,200 - 0,400 rendah, dan 0,000 0,200 sangat rendah. Teknik analisis data dilakukan melalui dua tahapan, yaitu analisis awal dan analisis akhir. Data awal/pretes diuji normalitas untuk mengetahui apakah data berdistribusi normal atau tidak. Data akhir/postes diuji normalitas dan selanjutnya dilakukan pengujian hipotesis dengan uji gain dan uji perbedaan dua rata-rata (uji t).

\section{HASIL PENELITIAN DAN PEMBAHASAN}

\section{Uji Validasi Instrumen}

Data uji instrument dengan penilain pakar didapat penilaian skor masing-masing aspek, penilai pakar pertama menyatakan 2 untuk kejelasan isi, kepaduan kelengkapan unsur 3, penggunaan kosakata 3, penggunaan kalimat akitif 3, serta sekor mekanis dalam penggunaan bahasa 1. Selanjutnya, pakar kedua memberikan penilaian 3-3-3-3-2 berturut setiap aspek. Artinya pakar pertama memberikan aspek kejelasan isi, kepadan kelengkapan unsur, penggunaan kosakata, pengunaan kalimat dikatakan relevan dan mekanisme penggunaan bahasa dinyatakan tidak relevan. Sedangkan pakar kedua menyatakan semua aspek relevan. Dari data ini, menunjukan jumlah nilai $\mathrm{A}=$ $0, \mathrm{~B}=0, \mathrm{C}=1$, dan $\mathrm{D}=4$. Setelah dimasukan kedalam rumus regeori diperoleh hasil perhitungan 0,8 . Maka instrument yang akan digunakan dalam penlitian ini memilik kriteria sedang.

\section{Uji Prasyarat}

Berikut ini akan dipaparkan hasil anlisis statistik deskriptif dan uji normalitas data kompetensi sikap, pengetahuan dan keterampilan siswa menulis genre teks prosedural.

\section{Hasil Analisis Data Aspek Sikap Siswa Menulis Genre Teks Prosedural}

Table 2. Hasil Statistik Deskriptif Postes Aspek Sikap

\begin{tabular}{cc}
\hline Statistik Deskriptif & Nilai Statistik \\
\hline Rata-rata & 72,01 \\
\hline Varians & 28,62 \\
\hline Standar deviasi & 5,35
\end{tabular}

Fakultas Keguruan dan Ilmu Pendidikan 
Table 3. Uji Normalitas Data Akhir/Postes Aspek Sikap

\begin{tabular}{cc}
\hline Sumber Variasi & Nilai Statistik \\
\hline $\boldsymbol{X}^{2}$ hitung & 2,9266 \\
\hline $\boldsymbol{X}^{2}$ tabel & 7,81 \\
\hline $\mathrm{dk}$ & 3 \\
\hline Kriteria & Normal \\
\hline
\end{tabular}

Dari perhitungan uji normalitas data postes aspek sikap siswa dalam kegiatan menulis teks genre prosedural diakui bahwa $\boldsymbol{X}^{2}$ hitung sebesar 2,9266 lebih kecil dibandingkan dengan $X^{2}$ tabel sebesar 7,81 atau $X^{2}$ hitung $<X^{2}$ tabel . Dengan ini, hasil perhitungan dinyatakan data aspek sikap siswa berdistribusi normal.

\section{Hasil Analisis Data Aspek Pengetahuan Siswa Menulis Genre Teks Prosedural}

Table 4. Hasil Statistik Deskriptif Postes Aspek Pengetahuan

\begin{tabular}{cc}
\hline Statistik Deskriptif & Nilai Statistik \\
\hline Rata-rata & 84,66 \\
\hline Varians & 27,65 \\
\hline Standar deviasi & 5,26 \\
\hline Ketuntasan & $75 \%$ \\
\hline
\end{tabular}

Table 5. Uji Normalitas Data Akhir/Postes Aspek Pengetahuan

\begin{tabular}{cc}
\hline Sumber Variasi & Nilai Statistik \\
\hline $\boldsymbol{X}^{\mathbf{2}}$ hitung & 7,67 \\
\hline $\boldsymbol{X}^{\mathbf{2}}$ tabel & 9,49 \\
\hline $\mathrm{dk}$ & 3 \\
\hline Kriteria & Normal \\
\hline
\end{tabular}

Berdasarkan tabel 5 hasil uji normalitas didapatkan $\boldsymbol{X}^{2}$ hitung hitung kelas berbasis proyek sebesar 7,670385 dengan $\boldsymbol{X}^{\mathbf{2}}$ tabel adalah 9,49 sehingga jelas bahwa $\boldsymbol{X}^{\mathbf{2}}$ hitung $<\boldsymbol{X}^{\mathbf{2}}$ tabel, maka data berdistribusi normal.

\section{Hasil Analisis Data Aspek Keterampilan Siswa Menulis Genre Teks Prosedural}

Table 6. Hasil Statistik Deskriptif Postes Aspek Keterampilan Menyusun Teks

\begin{tabular}{cc}
\hline Statistik Deskriptif & Nilai Statistik \\
\hline Rata-rata & 85 \\
\hline Varians & 28,28 \\
\hline Standar deviasi & 5,32 \\
\hline Ketuntasan & $78 \%$ \\
\hline
\end{tabular}


Table 7. Uji Normalitas Data Akhir/Postes Aspek Keterampilan

\begin{tabular}{cc}
\hline Sumber Variasi & Nilai Statistik \\
\hline $\boldsymbol{X}^{2}$ hitung & 5,390986 \\
\hline $\boldsymbol{X}^{2}$ tabel & 7,81 \\
\hline $\mathrm{dk}$ & 3 \\
\hline Kriteria & Normal
\end{tabular}

Berdasarkan tabel 7 hasil uji normalitas didapatkan $\boldsymbol{X}^{2}$ hitung untuk kelas berbasis proyek sebesar 5,390986 dengan $\boldsymbol{X}^{2}$ tabel adalah 7,81 sehingga jelas bahwa $\boldsymbol{X}^{2}$ hitung $<\boldsymbol{X}^{2}$ tabel, maka data berdistribusi normal.

\section{Pengujian Hipotesis}

Tabel 8. Output Uji N-gain Data Akhir/Postes Aspek Sikap

\begin{tabular}{lcc}
\multicolumn{1}{c}{ Kategori } & Jumlah & N-gain \\
Tinggi $(\mathrm{g}>0,7)$ & 0 & 0 \\
\hline Sedang $(0,7 \geq \boldsymbol{g} \geq \mathbf{0 , 3}$ & 12 & 33 \\
\hline Rendah $(\mathrm{g}<0,3)$ & 24 & 67 \\
\hline Jumlah & 36 & 100
\end{tabular}

Setelah mengetahui kriteria peningkatan sikap kemandirian peserta didik kelas model pembelajaran berbasis proyek baik secara klasikal maupun individual, dilakukan uji beda rata-rata berpasangan. Rumusan hipotesis uji beda ratarata berpasangan sikap kemandirian berdasarkan model pembelajaran yang diterapkan adalah sebagai berikut.

$\mathrm{H} 0: \mu_{B}=0$, berarti tidak terdapat perbedaan yang berarti antara rata-rata hasil pretes dan ratarata hasil postes sikap kemandirian peserta didik;

H1 : $\mu_{B}>0$, berarti terdapat perbedaan yang berarti antara rata-rata hasil pretes dan ratarata hasil postes sikap kemandirian peserta didik;

Hasil perhitungan yang dilakukan dengan uji diperoleh hitung $=7,69$. Diperoleh $1-\alpha$ dengan $=5 \%$ dan $d k=35$ adalah 1,68957. Berdasarkan kriteria uji $t$, karena $t$ Hitung $\geq t 1-\alpha$ maka $H 0$ ditolak. Jadi, dapat disimpulkan terdapat perbedaan yang berarti antara rata-rata hasil pretes dan rata-rata hasil postes sikap kemandirian peserta didik.

Tabel 9. Output Uji N-gain Data Akhir/Postes Aspek Pengetahuan

\begin{tabular}{lcc}
\multicolumn{1}{c}{ Kategori } & Jumlah & N-gain \\
\hline Tinggi $(\mathrm{g}>0,7)$ & 5 & 14 \\
\hline Sedang $(0,7 \geq \boldsymbol{g} \geq \mathbf{0 , 3}$ & 29 & 81 \\
\hline Rendah $(\mathrm{g}<0,3)$ & 2 & 6 \\
\hline Jumlah & 36 & 100 \\
\hline
\end{tabular}


Setelah mengetahui kriteria peningkatan pengetahuan menyusun teks prosedural peserta didik kelas model pembelajaran berbasis proyek baik secara klasikal maupun individual, dilakukan uji beda rata-rata berpasangan. Rumusan hipotesis uji beda rata-rata berpasangan pengetahuan menyusun teks prosedural berdasarkan model pembelajaran yang diterapkan adalah sebagai berikut.

$\mathrm{H} 0: \mu_{B}=0$, berarti tidak terdapat perbedaan yang berarti antara rata-rata hasil pretes dan ratarata hasil postes pengetahuan menyusun teks prosedural peserta didik;

H1 : $\mu B>0$, berarti terdapat perbedaan yang berarti antara rata-rata hasil pretes dan ratarata hasil postes pengetahuan menyusun teks prosedural peserta didik.

Hasil perhitungan yang dilakukan dengan uji diperoleh hitung $=16,32$. Diperoleh $1-\alpha$ dengan $=5 \%$ dan $d k=35$ adalah 1,68957. Berdasarkan kriteria uji $t$, karena $t$ Hitung $\geq t 1-\alpha$ maka $H_{0}$ ditolak. Jadi, dapat disimpulkan terdapat perbedaan yang berarti antara rata -rata hasil pretes dan rata-rata hasil postes pengetahuan menyusun teks prosedural peserta didik.

Berdasarkan analisis data peningkatan atau uji gain ternormalisasi kompetensi aspek sikap menunjukkan bahwa model pembelajaran berbasis proyek efektif dalam meningkatkan aspek sikap dengan kategori peningkatan rendah $(0,26<0,3)$. Jumlah peserta didik dengan kategori peningkatan tinggi $(\mathrm{g}>0,7)$ sebanyak $0(0 \%)$ peserta didik, kategori sedang $(0,7 \geq \mathrm{g} \geq 0,3)$ sebanyak $12(33 \%)$, dan kategori rendah $(\mathrm{g}<0,3)$ sebanyak $24(67 \%)$. Dari kompetensi sikap pada enam indikator menunjukkan bahwa terjadi peningkatan pada tiap aspek dengan rincian sebagai berikut; (1) aspek ketidaktergantungan dengan orang lain mengalami peningkatan sebesar 10,14; (2) aspek percaya diri mengalami peningkatan sebesar 10,94; (3) aspek disiplin mengalami peningkatan sebesar 6,81; (4) aspek tanggung jawab mengalami peningkatan sebesar 7,64; (5) aspek inisiatif mengalami peningkatan sebesar 10,69; dan (6) aspek kontrol diri mengalami peningkatan sebesar 8,19 dengan keseluruhan aspek mengalami peningkatan sebesar 8,71. Hasil penelitian yang dilakukan Febriastuti (2013) menyatakan bahwa pembeljaran berbasis proyek mampu meningkatkan kemandirian peserta didik dari perolehan nilai pretes sebesar 66,53 (kriteria cukup baik) dan setelah perlakuan diperoleh hasil sebesar 81,24 (kriteria baik). Perolehan uji n-gain sebesar 0,44 (kategori sedang).

Jika dibandingkan dengan aspek pengetahuan dan aspek keterampilan, aspek sikap merupakan aspek yang membutuhkan perlakuan yang lebih rumit. Sikap yang akan dinilai tidak selalu tampak pada setiap peserta didik, dengan keterbatasan waktu dan tenaga kegiatan penilaian sikap kurang optimal. Selain itu, untuk merubah sikap dengan karakteristik peserta didik yang beragam dibutuhkan ketelitian dalam segala tindakannya. Sementara pendidik juga harus melakukan monitoring untuk melihat kemajuan proyek maupun kesulitan yang dialami peserta didik. Penelitian yang dilakukan Damayanti et al. (2014) juga berpendapat bahwa dari hasil wawancara dengan guru, hambatan yang dialami dalam proses penilaian penerapan pembelajaran berbasis proyek yaitu hambatan dalam memberikan penilaian sikap yang harus dilakukan secara menyeluruh sedangkan waktu yang tersedia terbatas. Artinya penelitian yang dilakukan oleh Damayanti et al. (2014) secara deskriptif kualitatif bahwa penilaian sikap memiliki banyak hambatan sependapat dengan hasil penelitian secara deskriptif kuantitatif yang dilihat dari hasil uji gain yang memperoleh kategori peningkatan rendah. 
Uji gain ternormalisasi aspek pengetahuan diperoleh hasil secara klasikal sebesar 0,51 berada pada kategori sedang. Jumlah peserta didik dengan kategori peningkatan tinggi $(\mathrm{g}>0,7)$ sebanyak $5(14 \%)$ peserta didik, kategori sedang $(0,7 \geq \mathrm{g} \geq 0,3)$ sebanyak $29(81 \%)$ dan kategori rendah $(\mathrm{g}<0,3)$ sebanyak $2(6 \%)$. Hasil belajar berupa pengetahuan menyusun teks prosedural memperoleh rata-rata pretes sebesar 68,33 sedangkan postes sebesar 84,67. Hal tersebut menunjukkan bahwa model pembelajaran berbasis proyek efektif dalam meningkatkan kompetensi pada aspek pengetahuan. Perolehan rata-rata peserta didik pada kelas berbasis proyek sudah mencapai KKM, yakni 80. Meskipun nilai rata-rata sudah melampaui KKM, masih terdapat $9(25 \%)$ peserta didik yang mendapatkan nilai di bawah 80 . Kelas pembelajaran berbasis proyek, peserta didik yang mendapatkan predikat B sebanyak 9 peserta didik dan predikat A- sebanyak 27 peserta didik. Secara keseluruhan peserta didik kelas pembelajaran berbasis proyek tidak ada yang memperoleh predikat di bawah B.

Penelitian Purworini (2006) diperoleh data kuantitatif kemampuan pemahaman peserta didik berkaitan dengan teori (aspek kognitif) menggunakan model berbasis proyek meperoleh nilai rata-rata sebesar 76,48 lebih baik dari sebelum penerapan model yaitu sebesar 66,36. Penelitian Purworini menunjukkan bahwa penerapan model berbasis proyek dapat meningkatakan aspek pemahaman peserta didik dengan selisih skor mencapai 10,12.

Hasil penelitian Joko dan Rudi (2015) menunjukkan bahwa rata-rata hasil belajar mahasiswa berbeda atau mengalami peningkatan setelah menggunakan pembelajaran berbasis proyek. Didapat nilai rata-rata postes 81,50 dari nilai pretes 44,14. Rudi dan Joko (2015) berpendapat bahwa dengan menggunakan model pembelajaran berbasis proyek diharapkan mahasiswa dapat dengan mudah memahami materi yang disampaikan, sehingga meningkatkan hasil belajar. Penelitian Joko dan Rudi (2015) memperkuat hasil penelitian yang dilakukan oleh peneliti dari hasil peningkatan pada aspek pengetahuan menyusun teks prosedural, dapat disimpulkan bahwa pembelajaran berbasis proyek memiliki pengaruh pada aspek pengetahuan dengan hasil peningkatan dan rata-rata yang tinggi $(\mathrm{n} \geq 80)$. Sementara dibandingkan dengan Penelitian Purworini (2006), penelitian yang dilakukan Rudi dan Joko serta peneliti pada aspek pengetahuan mengalami peningkatan jumlah rata-rata menjadi lebih baik. 14,2. Jumlah peserta didik yang mencapai target 70\% yaitu aspek mekanik sebanyak 37 dengan persentase 97,3\%. Aspek penggunaan bahasa sebanyak 30 peserta didik dengan persentase 78,9\% dan aspek pembentukan bahasa sebanyak 28 peserta didik dengan persentase sebanyak 73,6\%. Selain itu penelitian Thitivesa dan Abigail Melad Essien (2013) menunjukkan bahwa ada perbedaan signifikan pada nilai signifikansi 0,05 sebesar $\mathrm{t}=101,699$ dengan $\mathrm{p}$-value $=0,000$ antara sebelum dan setelah perlakuan menggunakan model berbasis proyek.

\section{SIMPULAN}

Berdasarkan hasil analisis data dan pembahasan, maka dapat disimpulkan bahwa: (1) model pembelajaran berbasis proyek efektif dalam meningkatkan aspek sikap kemandirian belajar peserta didik kelas VIII yang dilihat dari hasil uji peningkatan dengan perolehan peningkatan aspek sikap secara klasikal berkategori rendah $(\mathbf{0 , 2 6}<0,3)$; (2) model pembelajaran berbasis proyek efektif dalam meningkatkan aspek pengetahuan menyusun teks prosedural peserta 
didik kelas VIII yang dilihat dari hasil uji peningkatan dengan perolehan peningkatan aspek pengetahuan secara klasikal berkategori sedang $(0,7 \geq \mathbf{0 , 5 1} \geq 0,3)$; (3) model pembelajaran berbasis proyek efektif dalam meningkatkan aspek keterampilan menyusun teks prosedural peserta didik kelas VIII yang dilihat dari hasil uji peningkatan dengan perolehan peningkatan aspek keterampilan secara klasikal berkategori sedang $(0,7 \geq \mathbf{0 , 5 2} \geq 0,3)$.

\section{DAFTAR PUSTAKA}

Hill. W.F., 2009. Theorie of Learning (teori-teori pembelajaran: konsepsi, komparasi, dan signifikasi). Bandung: Nusa Media.

Gintings, Abdorrakhman. 2008. Edisi Praktis Belajar \& Pembelajaran. Bandung: Humaniora.

Hendriyanto, Agoes \& Putri, N.P. 2002. Teori Belajar dan Pembelajar Bahasa. Surakarta: Cakrawala Media.

Mahsun. 2014. Teks dalam Pembelajaran Bahasa Indonesia. Jakarta: Rajawali Pers.

Hamdayama, Jumanta. 2014. Model dan metode pembelajaran kratif dan berkarater. Jakarta: Ghalia Indonesia.

Rusman. 2011. Mode-model pembelajaran mengembangkan prfesionalme guru. Jakarta: Rajawali Pers.

Iskandarwassid \& Sunendar, Dadang. 2013. Strategi Pembejaran Bahasa. Bandung: Rosada.

Djamarah, S.B \& Zain Aswan. 2010. Strategi Belajar Mengajar. Jakarta: Rineka Cipta.

Sudjana, Nana. 2010. Dasar-Dasar Proses Belajar Mengajar. Bandung: Sinar baru Algensindo.

Damayanti, Ni Komang Ayu et al. 2014. "Pembelajaran Menulis Teks Anekdot Berpendekatan Saintifik dengan Model Pembelajaran Berbasis Proyek (Project Based Learning) Pada Siswa Kelas X Tata Kecantikan Kulit 1 Di SMK Negeri 2 Singaraja”. e-Jounal Universitas Ganesha. Vol 2.No 1. Singaraja: Universitas Pendidikan Ganesha.

Joko dan Rudi. 2015. "Penerapan Model Pembelajaran Berbasis Proyek untuk Meningkatkan Hasil Belajar Mahasiswa pada Mata Kuliah Pemeliharaan dan Perbaikan Motor Listrik". Jurnal Pendidikan Teknik Elektro. Vol 03. No 04 Hlm 783-788. Tahun 2015.

Sugiyono. 2013. Metode Penelitian Pendidikan: Pendekatan Kuantitatif, Kualitatif, dan R\&D. Bandung: Alfabeta.

Thitivesa, Duangkamol. 2014. "The Academic Achievement of Writing via Project Based Learnig". International Journal of Social,Behavioral, Educational, Economic and Management Egineering. Volume 8, Nomor 9 Tahun 2014. 